Kohl: a Journal for Body and Gender Research

Vol. 1, No. 2 (Winter 2015)

\title{
Sex Tourism and the Military in Biomythographic Performances: An Interview with Jessika Khazrik
}

\author{
Ghiwa Sayegh
}

Jessika Khazrik has a BA in theater and linguistics. She is a writer, performer, and artist whose work converses with several fields and media. The different facets of her practice rotate around performance as she tries to touch upon remnants of a life and presence through acts of exhumation, infiltration, translation, and reclamation. Since 2014, she has been working under the platform of The Society of False Witnesses, which she founded while investigating a buried trade of toxic waste that was partially dumped three minutes away from where she grew up. Through this project, she looks at the notion of truth in all of science, art and the law and the ways in which they are reinforced on our bodies through the power they hold to attest and remember. In between her undergraduate study, Khazrik did the one year post-graduate program "Home Workspace" at Ashkal Alwan in 2012 - 2013, and is currently pursuing an MS in Art, Culture, and Technology at the Massachusetts Institute of Technology (MIT). Her work was performed, exhibited and published in different platforms and cities such as Aley, Aix-en-Provence, Beirut, Bern, Boston, Mannheim, Montemor-oNovo, and New York, just like her mother removed one mole in each of Pristina, Rabat, Paris, Rome, Los Angeles, Bangkok, and Yerevan.

On November 27, 2015, Ghiwa Sayegh, the editor in chief of Kohl: a Journal for Body and Gender Research conducted a Skype interview with Khazrik to better grasp the intersections of waste, military, and sex trades with biomythography ${ }^{1}$ and the erotic in her performances and projects.

\footnotetext{
${ }^{1}$ Biomythography is a form of writing and/or performance that combines myth, history, and biography together. It stems from African-American women literature, and speaks to women of color globally, as it subverts the traditional notion of history as "objective" and myth as deceptive. It combines a matrilineal transmission of history with the uses of the erotic as power.
} 

juxtapose with battlefields and the body?

Jessika Khazrik: I am seduced by how we perceive waste and their political economy. Honestly, it is very strange for me to be outside Lebanon at this specific time when the garbage crisis is reaching its peak and is leading to a political rupture. In Arabic, "wastes" or nifāyāt is derived from the verb "to exile," nafā - to exile matter, to exile the space that waste co-inhabits, hence making it inhabitable for others. This relates to the politics of the underground: in many ways, through our movements and understanding of our environments, we still perceive that the Earth is flat. But there are different strata of the Earth, of our thoughts... In that sense, physical exile and displacement remind me of the act digging and exhuming. The following excerpt was part of a new performance I made here, at the Military Industry of Terranova.

I don't give a shit because when I die I will move to live with trash. The nation was buried and the state has moved to the underground where borders are vertical and cardinal directions do not work, great! Do not search for time for this orb is a sun engulfed with ground and life does not end there until the Earth disappears. Gold is beautiful but soon, you will burn yourself. Ah, how much your perception of politics remains on the surface. O my eyes, if only you bury yourselves. ${ }^{2}$

Unfortunately, the recent protests that took place right before I had to leave - and specifically on August $22^{\text {nd }}$ - made me rethink the space of the battlefield and what it makes of bodies. As many artists from my generation and previous ones do, several of the questions I work on are related to the memory, suspension, and experience of the Lebanese Civil War(s). My coming to MIT further awakened this desire to look at the spatial politics of the battlefield, whether cyber or urban. I haven't encountered that yet as a subject matter or theme in any course, but it is normalized and treated as mundane and insidious in many academic contexts, though it can sometimes be more explicit. Through performance, I want to subvert the battlefield, unsheathe it, and play with it. There are many hidden battlefields that we don't deal with as such, especially that militarization now seeps into our everyday life.

GS: The hidden battlefields that you talk about are infused with imagery of the military institution when it comes to the globalized idea of trade. Why do you consider globalization and militarization feminist issues?

JK: One of my recently published essays looks at how Nahr Beirut serves the modern politics of exclusion and acts as a borderspace in relation to waste and exiled matter. Concurrently, in 1956, the Lebanese Ministry of Planning issued a decree to canalize the Beirut River, and the Lebanese state drew the borders of administrative Beirut, limiting its Northern line to the River bank. With this act of centralization, refugees

${ }^{2}$ A coupling of two Lebanese idiomatic phrases that parents often use to address separately/together their children; "O my eyes," "If only you bury me," "If only you bury my eyes," "O my eyes if only you bury my eyes." 
were excluded, and the river was eventually turned into a dump. Of course, displacement and decentralization are very much related to feminism: my personal experiences and research scrutinize the lens of race, class, and gender within the politics of space. War also displaces our bodies and attacks language: I have been delving into my mother's relationship with photography, citizenship, and skin, and creating different projects about the global politics and economies of sex tourism and toxic waste trades. My mother's master thesis was on the influence of sex work on tourism in Lebanon. Mine will be on the influence of militarization on academia and the ramifications and displacement of what is called today "disciplines."

\section{GS: How do you feel that the military interferes with the work of artists and academics?}

JK: I am against the ramifications of disciplines. I don't need to call what l'm doing art, or science, or literature, or performance. They all blend into each other. For instance, the military was able to find itself and normalize its work in the modern history of science by being one of the biggest hubs that funds the sciences. At the same time, nation-states were reinforced through the national presentation of artists in biennales, festivals, funding, etc. Borders at large, but artists and scientists as well, are instrumentalized to serve the purpose of governmental or military identity. Historically, in the context of MIT, a lot of funding was granted to artists in the seventies because art was perceived as "a way to 'humanize' the sciences." I am unsure what this even means.

\section{GS: If we go back to the idea of trade in relation to the military, how is it linked to sex tourism and how do you express that in your performances?}

JK: In 2013, I made a performance called "The influence of Prostitution on Tourism," after the title of my mother's MA thesis that she wrote in 1979. Through the narrative modes and tropes used in the performance, I got my audience to constantly question whether I'm saying that my mom is a sex worker. I attempted to touch on the years before my birth and inquire into the role of writers within the documents and fantasies they produce. For instance, at the end of the first act, I refer to Borges' essay, "The Wall and the Books," where he talks about the emperor who built the wall of China and burnt all the books that came before him. Borges analyzes this act of burning all precedent history as purely induced by an attempt to erase the memory of "his mother's infamy." In 1989, the Lebanese Forces and the Lebanese Army occupied the library of the Institute of Tourism where my mother studied, each from one side and separated by greenery. They left everything intact after their departure, but burnt the library, and with it, the second copy of mother's thesis. I am the sole owner of the first and last copy. Looking further into the dynamics of the global sex markets, my mother and I realized that post-colonial countries - where sex work is often legal - have actively established to this day sex markets whose clients predominantly come from the colonizing country - where sex work is often criminalized. In these relations, certain bodies are exoticized, fetishized, and perceived as more "sexual" than others. Adding to these complex dynamics, my performance sometimes replaced the civil war with the feminist sex wars that were taking place concurrently with my mother's thesis publication. From 1980 till 1990, my mother, who was studying nursing prior to tourism, fled the war to live in the clouds and in non-places. 


\section{GS: And how do you represent that idea of sex trade and tourism in connection with your mother?}

JK: The setting is super intimate. Our resemblance becomes a game: my face and my hands are dimly lit in a chiaroscuro of shadows and lights, reminiscent of my mother's academic erotic writing. The chasms between our times and modes of presence create a spectrality of uneasiness and love. It is mostly about writing, desire, history, and our feminisms. An iPad, turned into a book with stacks of paper of the same size clipped to its open case, is laying on my lap. I thoroughly remove one paper after the other, as if I am moving through my mother's strata of skin. I project a page from my mother's thesis, and I pause at the word "effeuilleuse," a French word for "stripper." Removing one paper after the other is my first enactment of "effeuiller." I project the intimate images of my mother via an iPad and create a live montage with the zooming in and out function, thus sexualizing the haptic/visual communication introduced by recent smart devices. Playing with the intervallic space found in both the photos and the silences, I intercalate in-between my speech, I posit narrative as an audience-constructed fantasy to be questioned. I work with 86 photographs out of more than 8012 that she has of herself. I plunge into thinking of the spectatorship of death, the transmission of post-memory, and the relationship between screen and skin.

to keep it short, effeuiller would be "to thin out the leaves of," or alternatively to move to turn, or remove one paper after the other. In this performance, through removing, peeling one paper after the other, I will be attempting to touch tales of skins my mother and I have invented.

Excerpt from "L'influence de la prostitution sur le tourisme," a performance by Jessika Khazrik, 2013.

\section{GS: This sounds a lot like a biomythographic performance to me...}

JK: It is! My mother was an airplane hostess. In the performance, I express the idea that my mother was a citizen of non-place and the subject of the photographs. Through them, she was able to transmit her citizenship to me. I was also born out of these images, and this is my way of fantasizing about and making fun of the Lebanese citizenship law. I analyze how the construction of women in Lebanon has trespassed the necessity of the rule of law. We are ungovernable. Through these myriad of photographs from her airborne years, my mother turned photography into a non-place and became the citizen of photographs. I, the citizen of photography, also believe that photographs were her skin. She would remove her moles in different places of the world, but I inherited her map of now-absent moles on my body. I also explicitly ask what if I had fallen in love with my mother, or with the woman of the photograph, or the woman I invented. Or what if I had fallen in love with the time before I was born. "What if I was born in 1991 but my memories were born before me, and I remember the war more than my mother does." The performance begins like this:

"L'influence de la prostitution sur le tourisme" or "The influence of prostitution on tourism" is a master's thesis written in 1979 by obviously a student at the Institute of Tourism named 
Georgette Karam. Its cover is made from leather, precisely vegetable-tanned cow skin. On its skin, we find slightly embossed white dots whose causes of emergence remain unknown. They are reminiscent of the 8 moles my mother has removed between 1980 and 1990 in Paris, Rabat, Pristina, Roma, Bangkok, Paris, Los Angeles, and Yerevan. Ibid.

GS: You invest a lot in the concepts of skin, memory, your mother, transmission of trauma, and remembrance. But what about the erotic, since it is deeply embedded in biomythographies?

JK: First, time is very erotic. I hate the past but it seduces me; this is the title of my upcoming performance, a radio play. I find my mother seductive, and her photographs are often very homoerotic - the way she would pose at home with her fellow flight attendant friends, the way they would touch each other's bodies... My curation of the photographs is quite explicit. My erotic gaze is brought forth through moving the images, time, and the act of rewriting. Some would call it incestuous, but in these questions and intimacies, I render parts of my mother's body and my desires public. 